\title{
PATH ANALYSIS ON THE DETERMINANTS OF TERTIARY PREVENTIVE BEHAVIOR AMONG PATIENTS WITH TYPE 2 DIABETES MELLITUS: APPLICATION OF THEORY OF PLANNED BEHAVIOR AND SOCIAL COGNITIVE THEORY
}

\author{
Yudi Andriyaningtiyas'), Didik Gunawan Tamtomo'), Bhisma Murti1) \\ 1)Masters Program in Public Health, Universitas Sebelas Maret \\ ${ }^{2)}$ Department of Public Health, Faculty of Medicine, Universitas Sebelas Maret
}

\begin{abstract}
Background: Global diabetes prevalence increases by $48 \%$. Primary prevention is particularly important in type 2 diabetes, because the time of diagnosis and the severity of the disease course can be influenced beneficially by changing daily lifestyle and dietary practices. The purpose of this study was to examine the determinants of tertiary preventive behavior among patients with type 2 diabetes mellitus using theory of planned behavior, social cognitive theory, and path model.

Subjects and Method: A cross sectional study was conducted at 25 community health centers in Bantul, Yogyakarta, Indonesia. A sample of 200 patients with type 2 DM was selected by exhaustive sampling. The dependent variable was tertiary preventive behavior toward type 2 DM. The independent variables were intention, attitude, self-efficacy, experience, modeling, self-regulation, outcome expectation, and subjective norm. The data were collected by questionnaire and analyzed by path analysis run on Stata 13 .

Results: Tertiary preventive behavior toward type 2 DM was directly increased by strong intention $(b=1.29 ; 95 \% \mathrm{CI}=0.48$ to $2.10 ; \mathrm{p}=0.002)$, positive attitude $(\mathrm{b}=2.06 ; 95 \% \mathrm{CI}=$ 1.26 to $2.85 ; \mathrm{p}<0.001)$, strong self-efficacy $(\mathrm{b}=1.38 ; 95 \% \mathrm{CI}=0.59$ to $2.18 ; \mathrm{p}=0.001)$, and strong modeling $(b=1.52 ; 95 \% \mathrm{CI}=0.66$ to $2.37 ; \mathrm{p}=0.001)$. It was indirectly affected by good experience, self-regulation, positive outcome expectation, and supportive subjective norm.

Conclusion: Tertiary preventive behavior toward type 2 DM was directly increased by strong intention, positive attitude, strong self-efficacy, and strong modeling. It was indirectly affected by good experience, self-regulation, positive outcome expectation, and supportive subjective norm.
\end{abstract}

Keywords: tertiary preventive behavior, type 2 diabetes mellitus

\section{Correspondence:}

YudiAndriyaningtiyas. Masters Program in Public Health, Universitas Sebelas Maret, Jl. Ir. Sutami 36A, Surakarta 57126, Central Java, Indonesia. Email: yudi.andriyaningtiyas@gmail.com. Mobile: +6281392704899.

The $7^{\text {th }}$ International Conference on Public Health

Solo, Indonesia, November 18-19, 2020 | 166 https://doi.org/10.26911/the7thicph.02.55 